\title{
MINERAL RESOURCE POTENTIAL OF THE WHEELER RIDGE ROADLESS AREA, INYO AND MONO COUNTTES, CALIPORNIA
}

\section{SUMMARY REPORT}

By

\author{
Michael A. Cosca and Maurice A. Chaffee \\ U.S. Geological Survey \\ and \\ Donald O. Capstick \\ U.S. Bureau of Mines
}

\section{STUDIES RELATED TO WILDERNESS}

Under the provisions of the Wilderness Act (Public Law 88-577, September 3, 1964) and related acts, the U.S. Geological Survey and the U.S. Bureau of Mines have been conducting mineral surveys of wilderness and primitive areas. Areas officially designated as "wilderness," "wild," or "canoe" when the act was passed were incorporated into the National Wilderness Preservation System, and some of them are presently being studied. The act provided that areas under consideration for wilderness designation should be studied for suitability for incorporation into the Wilderness System. The mineral surveys constitute one aspect of the suitability studies. The act directs that the results of such surveys are to be made available to the public and be submitted to the President and the Congress. This report discusses the results of a mineral survey of the Wheeler Ridge Roadless Area (5040), Inyo National Forest, Inyo and Mono Counties, California. The area was classified as a roadless area during the Second Roadless Area Review and Evaluation (RARE II) by the U.S. Forest Service, January 1979.

\section{SUMMARY}

Geologic and geochemical investigations and a survey of mines and prospects, conducted to evaluate the mineral resource potential of the Wheeler Ridge Roadless Area, Inyo and Mono Counties, Calif. (fig. 1), reveal several drainages within the south boundary of the roadless area that contain anomalous concentrations of one or more metallic elements. Because of these results, and the proximity to the Pine Creek mine, the southern part of the roadless area is considered to have $a$ low to moderate potential for tungsten and base and precious metals (fig. 2). The geologic setting is considered to be favorable for tungsten mineralization in tactite deposits along the margin of the Pine Creek roof pendant in the southern part of the roadless area. These drainages, however, may have been contaminated by nearby mines and haulage roads, which possibly contributed to the anomalous values in the samples. Resources were not identified at the three prospects located in the area.

\section{INTRODUCTION}

The Wheeler Ridge Roadless Area encompasses about 16,200 acres of Inyo National Forest on the east side of the Sierra Nevada, 17 mi northwest of Bishop and 20 mi southeast of Mammoth Lakes, Calif. The roadless area, which lies between 4,880 - and $13,748-\mathrm{ft}$ elevation, is semiarid and sparsely covered with sagebrush, juniper, pinon pine, and limber pine.

Analysis of geologic and geochemical data and information gathered at mines and prospects were used to evaluate the mineral resource potential of the Wheeler Ridge Roadless Area. The U.S. Bureau of Mines (USBM) conducted a detailed investigation of mines and prospects in or near the roadless area and examined records and published literature for information related to mineral deposits; the U.S. Geological Survey (USGS) conducted field and laboratory investigations of the roadless area in 1980 and 1981.

\section{GEOLOGY}

The map area (fig. 2) consists mainly of Mesozoic plutonic rocks and subordinate Paleozoic metamorphic rocks and Cenozoic (chiefly Quaternary) sedimentary deposits. The plutonic rocks are part of the Sierra Nevada batholith, and the metamorphic rocks are part of two large roof pendants.

Comprehensive geologic studies of the map area were published by Rinehart and Ross (1956, 1957, 1964) and Bateman (1965). The most current and comprehensive discussion of the mines and ore deposits in the Wheeler Ridge Roadless Area is in Rinehart and Ross (1964). Earlier reports on mineral deposits and mines in the study area include those by Hess and Larsen (1921), Lemmon (1941), and Tucker and Sampson (1941). The geology for this report was modified after Langenheim and others (1982), and Bateman (1965).

\section{Metamorphic rocks}

Metasedimentary rocks of Pennsylvanian(?) and Permian(?) age form the northern part of the Pine Creek roof pendant, which crops out in the southern part of the roadless area and extends northward as thin septa along Wheeler Crest. The rocks are mainly hornfels, quartzite, and marble and have been correlated on the basis of lithology with rocks $15 \mathrm{mi}$ to the northwest in the Mount Morrison roof pendant. Tactite deposits are also present in the metamorphic-rock sequence.

\section{Plutonic rocks}

Several plutonic bodies that crop out in the study area as part of the Sierra Nevada batholith are of Triassic and Jurassic and (or) Cretaceous age. They are present mainly along Wheeler Crest and sharply contact one another or are separated by thin septa of metamorphic rocks. The rocks are mostly granodiorite but also include diorite, quartz diorite, and hornblende gabbro. In general, the rocks were emplaced in order of increasing silica content. Some of the intrusions are zoned, with silica content increasing toward the center.

Bodies of heterogeneous diorite, quartz diorite, and 
hornblende gabbro that occur within the large silicic plutons seem to be associated with the metamorphic rocks becaused many of these bodies contain metamorphic inclusions. The age relations of the many mafic bodies in the study area are not known. A quartz diorite body near the Pine Creek mine in the southwestern part of the roadless area has been dated by the uranium-lead method at $169 \mathrm{~m} . y$. (Stern and others, 1981). Diorite and gabbro bodies in the Mount Morrison and Casa Diablo Mountain quadrangles are probably Jurassic or Cretaceous (R. W. Kistler, oral commun., 1981).

The oldest plutonic rock is the Wheeler Crest Quartz Monzonite, the most extensively exposed unit in the area, which crops out principally on the steep eastern face of Wheeler Crest between Pine and Hilton Creeks. The Wheeler Crest Quartz Monzonite is dominantly porphyritic but grades into equigranular rock with a texture identical to that in the groundmass of the porphyritic rocks. Most of the quartz monzonite has a primary foliation and, locally, a secondary gneissic foliation. The Wheeler Crest Quartz Monzonite is intruded by all the plutonic rocks with which it is in contact, except for quartz diorite and hornblende gabbro. The Wheeler Crest Quartz Monzonite has been dated by the uranium-lead method on zircon at about $207 \mathrm{~m} . \mathrm{y}$. (Stern and others, 1981).

The Tungsten Hills Quartz Monzonite crops out in the southern part of the roadless area in two main bodies separated by the Pine Creek roof pendant. These bodies probably were originally parts of different plutons. With few exceptions, the Tungsten Hills Quartz Monzonite is homogeneous in both composition and appearance. This unit intrudes the Wheeler Crest Quartz Monzonite and is considered to be Triassic in age.

The Jurassic and (or) Cretaceous granitic rocks in the roadless area range in composition from granodiorite to alaskite and form plutons of varying shape and size, many of which are elongate and parallel to the axis of the Sierra Nevada. Common accessory minerals in the granitic rocks are magnetite, ilmenite, sphene, apatite, zircon, and allanite; equigranular textures are more common than porphyritic ones.

The Round Valley Peak Granodiorite is a very extensive granitic unit that forms a single mass along Wheeler Crest. The Round Valley Peak has been dated radiometrically by the uranium-lead method at about $90 \mathrm{~m} . \mathrm{y}$. (Stern and others, 1981).

A large body of quartz monzonite, termed the "finer grained quartz monzonite" by Bateman (1965), occurs along the east side of Wheeler Crest. This body also occurs as four separate masses south and southeast of the roadless area. The quartz monzonite intrudes the Wheeler Crest Quartz Monzonite, but its relations with rocks younger than the Wheeler Crest are unknown.

Other granitic rocks occur as separate small masses. The granodiorite of Red Mountain is exposed on the east flank of Red Mountain 2 mi northwest of the roadless area; the quartz monzonite of Hilton Creek occurs as two small bodies on the east side of Hilton Creek; and the albite granite of McGee Mountain, considered to be an albitized equivalent of the quartz monzonite of Hilton Creek, occurs on the east side of McGee Mountain $6 \mathrm{mi}$ northwest of the study area. A small part of the very extensive Lamarck Granodiorite is within the study area. An alaskite similar to the Cathedral Peak Granodiorite crops out in a narrow elongate band on the east side of Wheeler Crest.

\section{Sedimentary deposits}

The sedimentary deposits in the roadless area are mainly glacial, alluvial, or colluvial in origin. Most of the glacial deposits form well-defined moraines at the mouths of the major canyons, but erratics and small patches of till lie on some upland surfaces.

Alluvium, considered to be of Tertiary age, forms a thin mantle underlying remnants of ancient land surfaces that bevel the Sierra Nevada front about 3,000 to $5,000 \mathrm{ft}$ above the adjacent valley floor. Alluvial fill, alluvial-fan deposits, and talus of Quaternary age lie on the floors and slopes of canyons and in the adjacent Owens Valley.

\section{Structure}

The major structural features in the study area are related to periods of deformation. The oldest structures include intrusive folds in the Paleozoic sedimentary sequence that were formed during a prebatholithic regional deformational event. A second group of structures, which were formed by the intrusion of the Sierra Nevada batholith, are exhibited by additional folding and faulting. Folds and faults related to the regional deformation cannot always be readily distinguished from those related to the intrusion of the batholith. The youngest structures are Cenozoic faults related to uplift along the Sierra Nevada front.

The largest pre-Cenozoic structure in the area is an overturned homoclinal west-dipping sequence of Paleozoic rocks that makes up the Pine Creek roof pendant. Major and minor folds, many of which are steeply plunging and tightly folded, are related to apparent lateral movement along faults. Gently to moderately plunging folds also occur but are not so common as the steeply plunging folds.

Major faults occur along the southwest slope of McGee Mountain, along the west side of Hilton Creek, and near the top of Wheeler Crest. Most of these faults are steeply dipping and have a northwest trend. The age of faulting is not known, but the faults are inferred to be contemporaneous with the granitic intrusion. A few faults east of Hilton Creek on the slopes of Wheeler Crest are perpendicular to the general trend.

The dominant Cenozoic structures are high-angle normal faults and gentle warps that are related to uplift of the Sierra Nevada. The oldest of these faults cut rocks of Cenozoic age and may be late Miocene. The escarpment along the east face of the Sierra Nevada near Wheeler Crest, a good example of this young basin-and-range faulting, is one of the highest and most precipitous along the Sierra Nevada front. The fault zone at the base of the escarpment north of Pine Creek is made up of interconnecting straight or gently curved segments in an almost continuous line of faults covered locally by Quaternary deposits. The roadless area is currently undergoing deformation, as evidenced by recent $(1979,1980,1981,1982,1983)$ earthquake swarms occuring in the Convict Lake area.

\section{GEOCHEMICAL STUDIES}

The USGS collected and analyzed 18 rock, 27 streamsediment, and 29 panned-concentrate samples for the geochemical study of the roadless area. All the samples were analyzed for 31 elements (silver, arsenic, gold, boron, barium, beryllium, bismuth, calcium, cadmium, cobalt, chromium, copper, iron, lanthanum, magnesium, manganese, molybdenum, niobium, lead, antimony, scandium, tin, strontium, thorium, titanium, uranium, vanadium, tungsten, yttrium, zinc, and zircon), using a six-step semiquantitative emission-spectrographic method (Grimes and Marranzino, 1968). Rock and stream-sediment samples were also analyzed for zine by atomic-absorption spectrometry (Ward and others, 1969), and some were analyzed for gold by the same technique (Meier, 1980). Stream-sediment samples were analyzed for uranium, using a modification of the fluorometric method of Centanni and others (1956). The geochemical data are given in Cosca and Chaffee (1983).

Rock samples were collected by the USGS from relatively unaltered areas and provide information on the normal or background chemical abundances of the rock units present in the roadless area. The stream-sediment and nonmagnetic-heavy-mineral-concentrate samples provide information about the drainage basins upstream from the sample site. This information was used to identify drainages with anomalous occurrences of selected elements possibly related to mineralization.

For the USGS's rock samples, six elements (silver, gold, copper, molybdenum, tungsten, and zinc) were selected as possibly related to mineralization. A total of 10 (silver, arsenic, gold, barium, bismuth, copper, molybdenum, lead, tungsten, and zinc) elements were investigated in the streamsediment samples, and 11 elements (silver, arsenic, gold, barium, bismuth, copper, molybdenum, lead, uranium, 
tungsten, and zinc) were selected in the heavy-mineralconcentrate samples as related to mineralization; two elements (cobalt, iron) were considered to be related to hydrothermal alteration (pyritization).

The USGS then divided the roadless area into drainage basins corresponding to each sample locality. Anomalous concentrations of the selected elements were recorded for each drainage basin, totaled, and a numerical score assigned on the basis of the total; drainages with the highest scores represent areas of greatest mineral resource potential. The geochemical anomalies were then correlated with the geologic features.

In addition, 19 rock samples were collected by the USBM at prospects and outcrops suspected of containing anomalous concentrations of certain metallic elements. Analyses of these samples were made to indicate qualitatively the presence or absence of these minerals. The results were used to calculate resources at mines, prospects, and mineralized outcrops or to indicate areas of site-specific mineral resource potential.

\section{MINING DISTRICTS AND MINERALIZED AREAS}

Mining in the Bishop district, which includes the Wheeler Ridge Roadless Area, began in the late 1800 's. Tungsten was discovered in 1913 , but mining did not begin until 1916. Tungsten prices reached unprecedented heights in 1916, and with production underway, many new discoveries were soon to be made. After World War I, collapse of the price of tungsten forced the mines to close. During the 1930 's, tungsten mining was intermittent, and many miners focused their energy more toward gold production. Production increased during World War II, when the price and sale of tungsten concentrates were fixed by Federal law (Bateman, 1965). Postwar halting of Government purchases caused the price of tungsten to fall and forced the eventual closure of most operations. Peak production from the Bishop district was reached during the Korean War, and moderate demands continued throughout the 1970's to maintain a Government stockpile.

In addition to tungsten, the Bishop district has yielded sizable amounts of gold, silver, molybdenum, and copper. Nonmetallic deposits of pumice, perlite, barite, talc, building stone, ceramic materials, gravel, and limestone also have been mined (Bate man, 1965).

Bordering the south end of the Wheeler Ridge Roadless Area are several tungsten mines, including one of the largest tungsten producing mines in the world, the Pine Creek mine (which includes the Adamson, Panaminius, and Brownstown mines), currently owned by the Union Carbide Corp. (Newberry, 1982). Though not currently in operation, the Pine Creek mine has operated more or less continuously since 1916. The mine has produced a sizable proportion of the world's tungsten supply, in addition to economic concentrations of molybdenum, gold, silver, and copper. Table 1 summarizes the data on prospects in the roadless area.

\section{ASSESSMENT OF MINERAL RESOURCE POTENTIAL}

Analyses of stream-sediment and heavy-mineralconcentrate samples indicate that several drainages in the southern part of the roadless area contain anomalous concentrations of selected elements possibly related to mineral deposits. Anomalous concentrations of one or more of the elements silver, arsenic, barium, bismuth, copper, molybdenum, lead, tungsten, and zine were detected in drainages originating on Wheeler Crest and draining to the southeast and southwest in the vicinity of Mt. Morgan (Cosca and Chaffee, unpub. data). These elements are common to mineral deposits formed by hydrothermal activity-in particular, contact-metasomatic tungsten skarn deposits and (or) base- and precious-metal vein deposits. These elements, particularly tungsten and molybdenum, have been extracted in large amounts from the Pine Creek roof pendant, a small part of which occurs in the southwestern part of the roadless area. The geochemical anomalies and tungsten occurrences at the prospect east of Round Valley Peak, as well as the historical production figures, suggest that a low to moderate potential for the discovery of tungsten and (or) base- and precious-metal deposits exists in the southern part of the Wheeler Ridge Roadless Area.

\section{REFERENCES CITED}

Bateman, P. C., 1965, Geology and tungsten mineralization of the Bishop district, California: U.S. Geological Survey Professional Paper 470, 208 p.

Centanni, F. A., Ross, A. M., and DeSesa, M. A., 1956, Fluorometric determination of uranium: Analytical Chemistry, v. 28, no. 11, p. 1651-1657.

Cosca, M. A., and Chaffee, M. A., 1983, Geochemical analyses of rock, stream-sediment, and pannedconcentrate samples from the Laurel-McGee and Wheeler Ridge Roadless Areas, Inyo and Mono Counties, California: U.S. Geological Survey OpenFile Report 83-3, $107 \mathrm{p}$.

Grimes, D. J., and Marranzino, A. P., 1968, Direct-current arc and alternating-current spark emission spectrographic field methods for the semiquantitative analysis of geologic materials: U.S. Geological Survey Circular 591, 6 p.

Hess, F. L., and Larsen, E. S., 1921, Contact metamorphic tungsten deposits of the United States: U.S. Geological Survey Bulletin 725-D, p. 245-309.

Langenheim, V. A. M., Donahoe, J. L., and McKee, E. H., 1982, Geologic map of the Laurel-McGee and Wheeler Ridge Roadless Areas, Inyo and Mono Counties, California: U.S. Geological Survey Miscellaneous Field Studies Map, MF-1411-A, scale 1:62,500.

Lemmon, D. M., 1941, Tungsten deposits in the Sierra Nevada near Bishop, California: A preliminary report: U.S. Geological Survey Bulletin 931-E, p. 79-104.

Meier, A. L., 1980, Flameless atomic-absorption determination of gold in geological materials: Journal of Geochemical Exploration, v. 13, no. 1, p. 77-85.

Newberry, R. J., 1982, Tungsten-bearing skarns of the Sierra Nevada. 1. The Pine Creek mine, California: Economic Geology, v. 77, no. 4, p. 823-844.

Rinehart, C. D., and Ross, D. C., 1956, Economic geology of the Casa Diablo Mountain quadrangle, California: California Division of Mines and Geology Special Report 48, 17 p.

1957, Geology of the Casa Diablo Mountain quadrangle, California: U.S. Geological Survey Geologic Quadrangle Map GQ-99, scale 1:62,500.

1964, Geology and mineral deposits of the Mount Morrison quadrangle, Sierra Nevada, California: U.S. Geological Survey Professional Paper 385, 106 p.

Stern, T. W., Bateman, P. C., Morgan, B. A., Newell, M. F., and Peck, D. L., 1981, Isotopic U-Pb ages of zircon from the granotoids of the central Sierra Nevada, California: U.S. Geological Survey Professional Paper $1185,17 \mathrm{p}$.

Tucker, W. B., and Sampson, R. J., 1941, Recent developments in the tungsten resources of California: California Journal of Mines and Geology, v. 37, no. 4, p. 565-588.

Ward, F. N., Nakagawa, H. M., Harms, T. F., and VanSickle, G. H., 1969, Atomic-absorption methods of analysis useful in geochemical exploration: U.S. Geological Survey Bulletin 1289, 45 p. 


\begin{tabular}{|c|c|c|c|c|}
\hline \multicolumn{2}{|c|}{ Prospect } & \multirow[b]{2}{*}{ Surmary } & \multirow[b]{2}{*}{ Work1ngs } & \multirow[b]{2}{*}{$\begin{array}{l}\text { Sample results and } \\
\text { resource estimate }\end{array}$} \\
\hline $\begin{array}{l}\text { Map No. } \\
\left(\text { fig. }^{2}\right)\end{array}$ & Name & & & \\
\hline 1 & Unknown -- & $\begin{array}{l}\text { L1monite(?) pod at } \\
\text { hornfels-marble contact. }\end{array}$ & 1 small p1t - & $\begin{array}{l}\text { One sample from } 11 \text { monite pod } \\
\text { ylelded } 0.32 \text { weight percent } \\
\text { capper and } 0.54 \text { wef ght percent } \\
\text { zinc. No resource Identfied. }\end{array}$ \\
\hline 2 & $---d o-C$ & $\begin{array}{l}\text { Shear zone in hornfels } \\
\text { malachite/azurite stains. }\end{array}$ & 3 small pits - & $\begin{array}{l}\text { Three samples from shear zone } \\
\text { ylelded } 1.37,0.02 \text {, and } 0.16 \\
\text { welght percent copper. One } \\
\text { sample y1elded } 0.01 \text { weight } \\
\text { percent Wo (tungsten } \\
\text { trloxide). No resources } \\
\text { 1dentifled. }\end{array}$ \\
\hline 3 & $\begin{array}{l}\text { Round Valley } \\
\text { Peak }\end{array}$ & Garnet-epidote-quartz & $\begin{array}{l}11 \text { ohallow } \\
\text { exploratory } \\
\text { bul1dozer } \\
\text { trenches and } \\
\text { hand-dug p1ts. }\end{array}$ & $\begin{array}{l}\text { of nine samples, two select } \\
\text { samples yfelded } 0.20 \text { and } 0.06 \\
\text { welght percent } \mathrm{WO}_{3} ; \text { two chip } \\
\text { sapples contalned } 0.13 \text { and } 0.06 \\
\text { welght percent } \mathrm{WO}_{3} \text {. }\end{array}$ \\
\hline
\end{tabular}

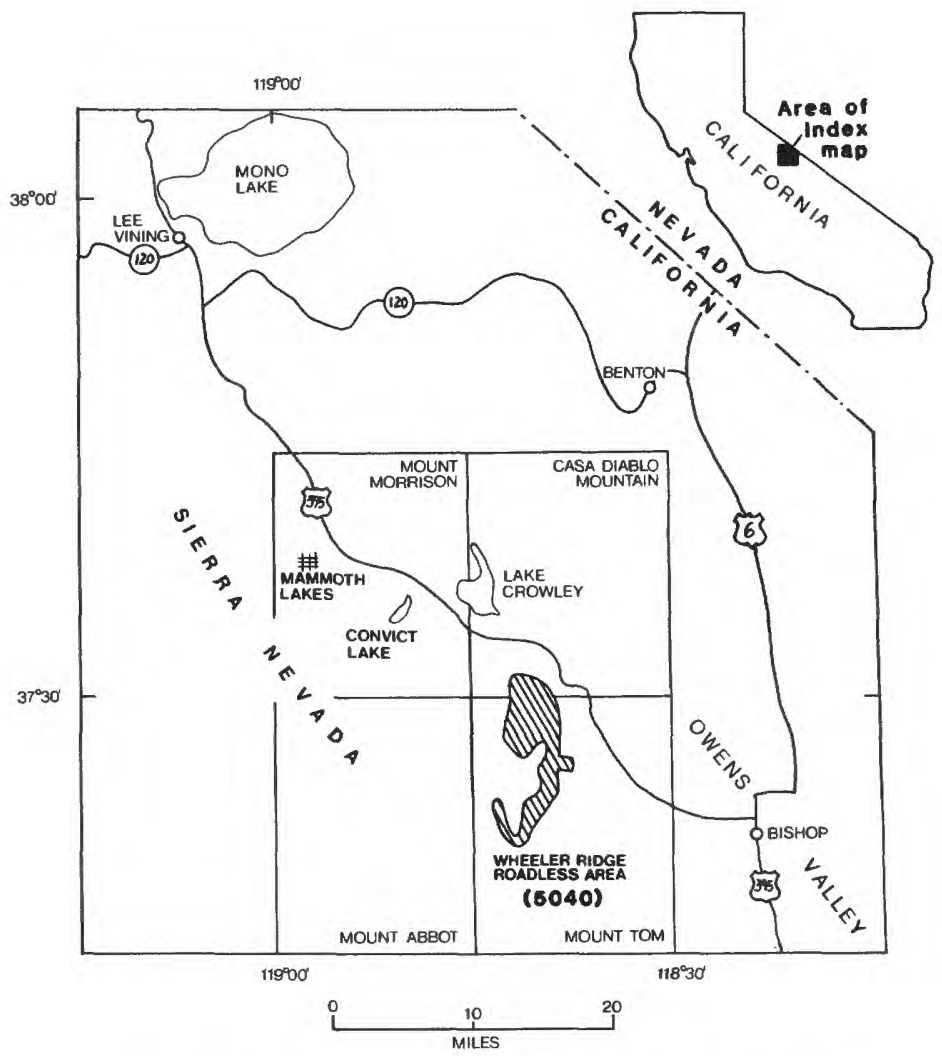

Figure 1.-Index map of east-central Callfornia showing location of the Wheeler Ridge Roadiess Area and the 16-minute quadrangles that cover the area 


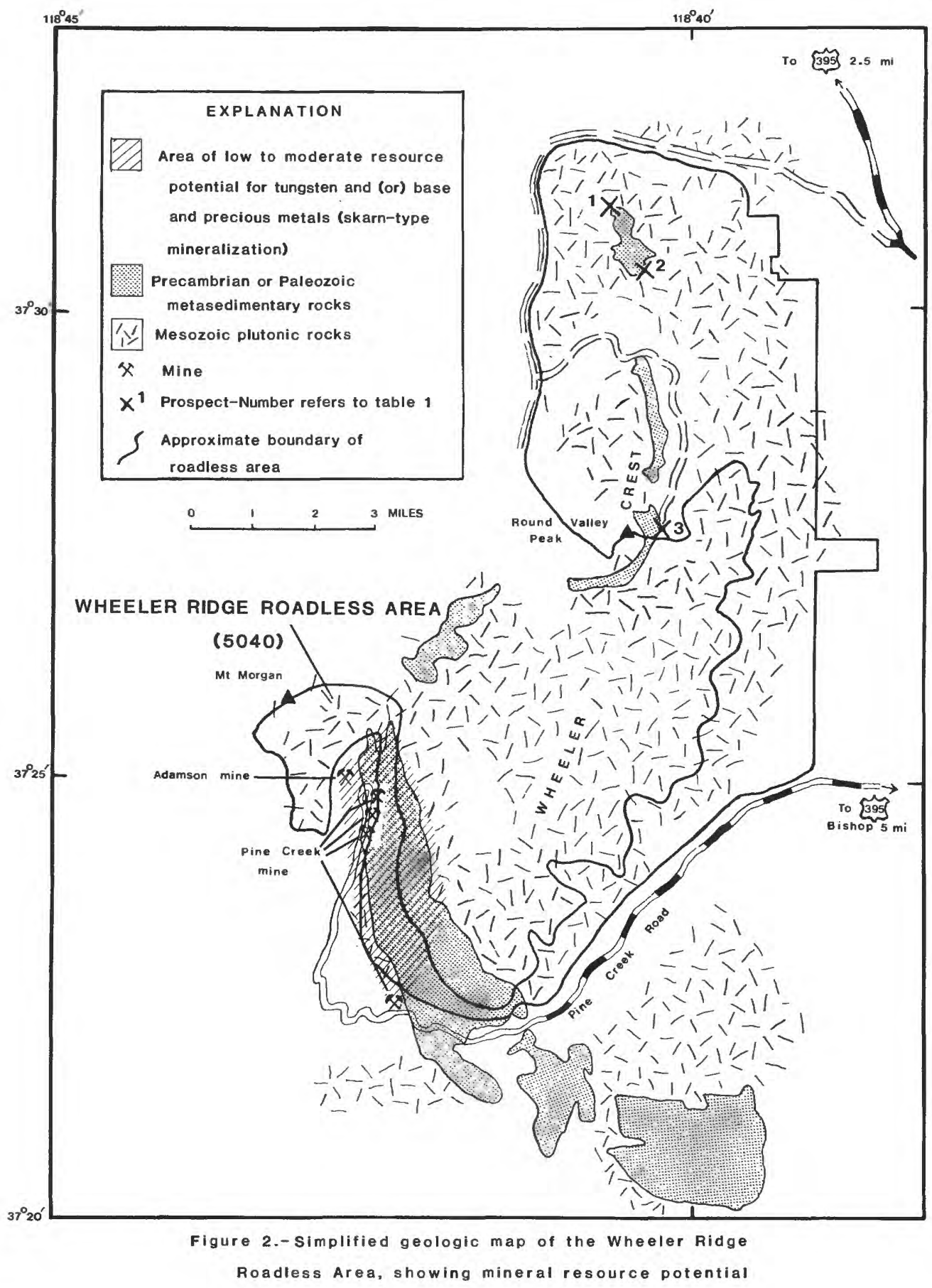


